\title{
BILATERAL CHANGES IN THE LUNGS OF A PREGNANT WOMAN CAUSED BY BILATERAL SPONTANEOUS PNEUMOTHORAX
}

Jelena Radojicic ${ }^{1}$, Jelena Markovic ${ }^{2}$, Zeljko Garabinovic ${ }^{3}$, Milan Savic ${ }^{3,4}$, Jelena Stojsic ${ }^{2}$

${ }^{1}$ City Institute for Urgent Medical Care, Belgrade, Serbia

${ }^{2}$ Service of Pathology, Clinical Center of Serbia, Belgrade, Serbia

${ }^{3}$ Clinic of Thoracic Surgery, Clinical Center of Serbia, Belgrade, Serbia

${ }^{4}$ Faculty of Medicine, University of Belgrade, Belgrade, Serbia

\author{
BILATERALNE PROMENE U PLUĆIMA TRUDNICE IZAZVANE \\ BILATERALNIMI SPONTANIM PNEUMOTORAKSOM \\ Jelena Radojičić ${ }^{1}$, Jelena Marković ${ }^{2}, Z_{\text {Zeljko Garabinović3 }}$, Milan Savić3, ${ }^{3,4}$ Jelena Stojšić ${ }^{2}$ \\ ${ }^{1}$ Gradski institut za hitnu medicinsku negu, Beograd, Srbija \\ ${ }^{2}$ Služba za patologiju, Klinički centar Srbije, Beograd, Srbija \\ ${ }^{3}$ Klinika za torakalnu hirurgiju, Klinički centar Srbije, Beograd, Srbija \\ ${ }^{4}$ Medicinski fakultet, Univerzitet u Beogradu, Beograd, Srbija
}

\begin{abstract}
Lymphangioleiomyomatosis (LAM) is a rare disease that most commonly affects women of reproductive age. The disease is manifested by diffuse destruction of the pulmonary parenchyma with the formation of cysts on a characteristic finding of multidetector computerized tomography (MD-CT) of the chest. It is thought that the presence of cells with estrogen and progesterone receptors among proliferating smooth muscle cells lead to the spread of cystic structures lined by endothelial cells. Towards the end of pregnancy and after childbirth, collapse of the lung parenchyma or rupture of the cyst wall occurs causing a dramatic clinical picture in the form of pneumothorax. Sirolimus is the only drug of choice that should improve and stabilize the patient's pulmonary function and quality of life. Unfortunately, this drug is not always effective enough, so only option for treatment is bilateral lung transplantation.

The authors present the patient in the last trimester of pregnancy who was admitted to the hospital with clinical picture of bilateral spontaneous pneumothorax. Dramatic picture of pneumothorax could not be solved solely by drainage in which atypical segmental resection of the lung was performed within a few days so on these samples lymphangioleiomyomatosis were diagnosed.
\end{abstract}

Keywords: lymphangioleiomyomatosis, pneumothorax, pregnancy, dysregulation of estrogen receptor, dysregulation of progesterone receptor, proliferation of smooth muscle, lymphangiectasia, proliferation of $H B M-45$ cells.

\section{SAŽETAK}

Limfangioleiomiomatoza (LAM) je retko oboljenje koje najčešće zahvata žene u reproduktivnom periodu života. Bolest se manifestuje difuznom destrukcijom plućnog parenhima sa stvaranjem cisti na karakterističnom nalazu multidektor kompjuterizovanom tomografijom (MD-CT) grudnog koša. Smatra se da prisustvo ćelija sa estrogen i progesteron receptorima među proliferisalim glatkomišićnim ćelijama dovodi do širenja cističnih struktura obloženih endotelnim ćelijama. Pred kraj trudnoće i posle porođaja dolazi do kolapsa parenhima ili rupture zida ciste uzrokujući dramatičnu kliničku sliku u vidu pnumotoraksa. Sirolimus je jedini lek izbora koji treba da poboljša i stabilizuje plućnu funkciju i kvalitet života pacijenta. Na žalost, ovaj lek nije uvek dovoljno efikasan, pa je jedina mogućnost za lečenje obostrana transplantacija pluća.

Autori prezentuju pacijentkinju u poslednjem trimestru trudnoće koja je u bolnicu primljena sa obostranom slikom spontanog pneumotoraksa. Dramatična slika pneumotoraksa nije mogla biti rešena samo drenažom kod koje je u roku od nekoliko dana izvršena atipična segmentalna resekcija pluća, pa je na tim uzorcima postavljena dijagnoza limfangioleiomiomatoze.

Ključne reči: limfangioleiomiomatoza, pneumotoraks, trudnoća, disregulacija estrogen receptora, disregulacija progesteron receptora, glatkomišićna proliferacija, limfangiektazije, proliferacija HBM-45 ćelija. 


\section{INTRODUCTION}

The diagnosis of rare lung tumors is a challenge. Some rare lung tumors are diagnosed only once during the years of practicing pulmonary pathology and that only in highly specialized hospitals exclusively dealing with thoracic surgery. According to the latest WHO classification, lymphangioleiomyomatosis (LAM) belongs to the group of mesenchymal tumors, subgroup of PEComatous tumors. In the literature, LAM has been described as a tumor associated with tuberous sclerosis. Pneumothorax and acute respiratory distress syndrome are the leading symptoms of LAM $[1,2]$. The literature describes patients who have been diagnosed with LAM in pregnancy and who have had to have a premature birth [3, 4]. Radiological findings as well as pathohistological, morphological and immunohistochemical findings were characteristic of LAM [5].

We present a patient who developed bilateral spontaneous pneumothorax in the last trimester of pregnancy.

\section{CASE REPORT}

We present a case of 32-year-old pregnant woman and non-smoker who was hospitalized at the Clinic for Thoracic Surgery Clinic of the Clinical Center of Serbia, Belgrade, Serbia, in February 2020 for bilateral chest pain and shortness of breath. Because of suspicion to bilateral spontaneous pneumothorax after reviewing radiological findings, it was performed multidetector -computed tomography (MD-CT). MD- CT cross-sectional imaging has determined bilateral diffuse cystic changes of thin and smooth wall both directly below the pleura and deep within the lung parenchyma [Figure $1 \mathrm{a}, 1 \mathrm{~b}]$. It was concluded that reexpansion of the pulmonary parenchyma could not be solved only by bilateral drainage but only by surgical procedure.

In order to perform surgery, c-section performed in $37^{\text {th }}$ week of pregnancy at the Clinic for Gynecology and Obstetrics of the Clinical Center of Serbia in Belgrade, was necessary. Thereafter, it was performed atypical segmental resection on the left lung and after a few days, resection of the same type to the right lung.

\section{Pathological findings:}

One day before macroscopic examination and sampling, insufflation of $10 \%$ buffered formalin was performed in order to make easier examination of distended alveolar spaces by imitating inspirium.

Macroscopic finding: Routine macroscopical examination of sample showed smooth wall cavities with no noticeable content, up to $4 \mathrm{~mm}$ in diameter, which were present below the pleura and also in the depth of the pulmonary parenchyma. Because of this, both lung samples had a sponge-like appearance [Figure 1c]. Tissue samples were routinely processed, embedded into paraffin blocks and classically hematoxylin-eosin stained.
Figure 1. Radiological and macroscopic findings.

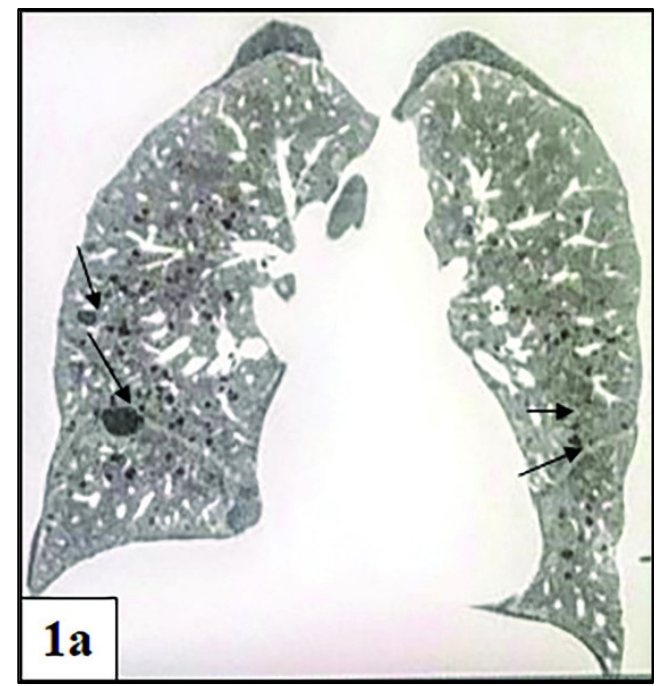

Figure 1a. Apical computed tomography of the chest detected numerous diffuse thin-walled cysts of various dimensions without content (arrows)

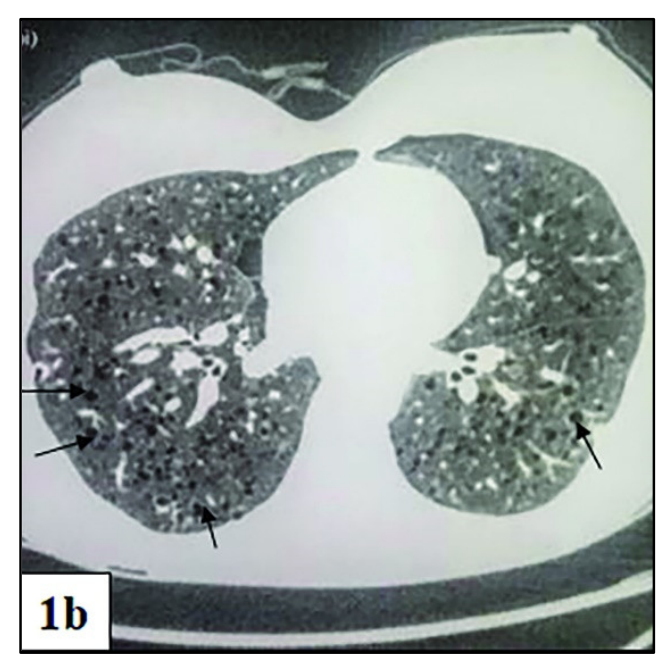

Figure 1b. Apicoaxial computed tomography of the chest: numerous thin-walled cysts without content (arrows) diffusely presented in the lung parenchyma and subpleuraly 


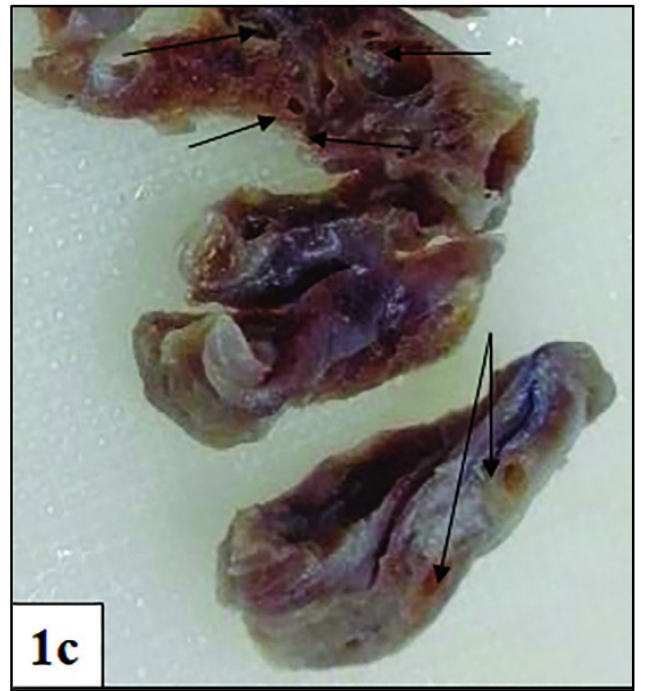

Figure 1c. Macroscopic findings: diffuse cystic spaces of the thin and smooth walls, without content.

On this sample, the greatest measured diameter is up to $4 \mathrm{~mm}$ (arrows)

Macroscopic changes were less pronounced on the sample from the right lung, operated one week later.

Suspicion on lymphangioleiomyomatosis arose after H\&E staining which has also immunohistochemically proven.

Microscopic finding: In the lung parenchyma were present numerous cystic spaces without content covered by single-row endothelial cells. Under endothelial cells focally have located multiplied spindle cells expressing $\alpha$-smooth muscle $(\alpha S M)$ actin marker (Figures $2 \mathrm{a}, \mathrm{b}, \mathrm{c})$. Between these cells are those that express steroid receptors, estrogen and progesterone (Figures 2d, e). The main characteristic is the presence of diffuse cytoplasmic expression of HBM-45 in almost all spindle cells (Figure 2f).

Figure 2. Microscopic findings

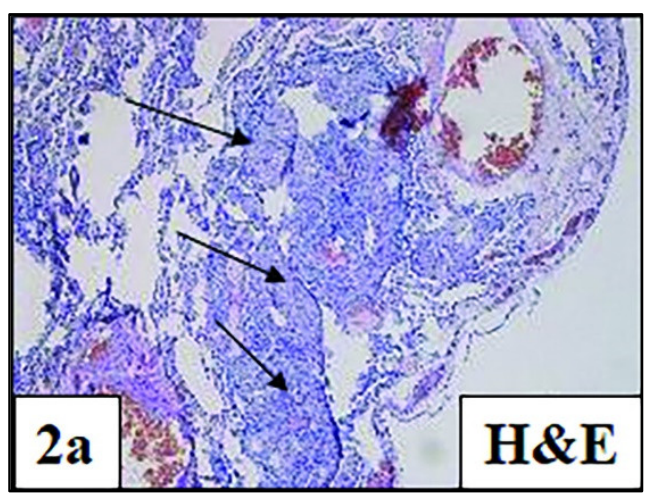

Figure 2a. Diffuse changes in the lung parenchyma in the wall of cystic spaces of proliferative spindle cells (arrows) x 10

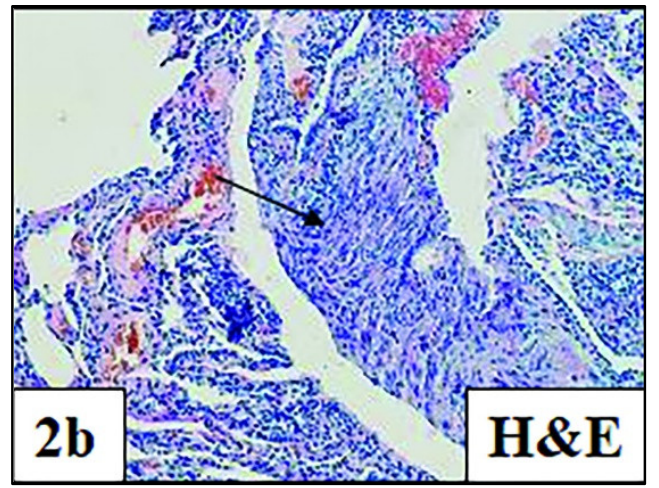

Figure 2b. One of the focuses of proliferating spindle cells in the wall of the cystic lung structure (arrow) x 20

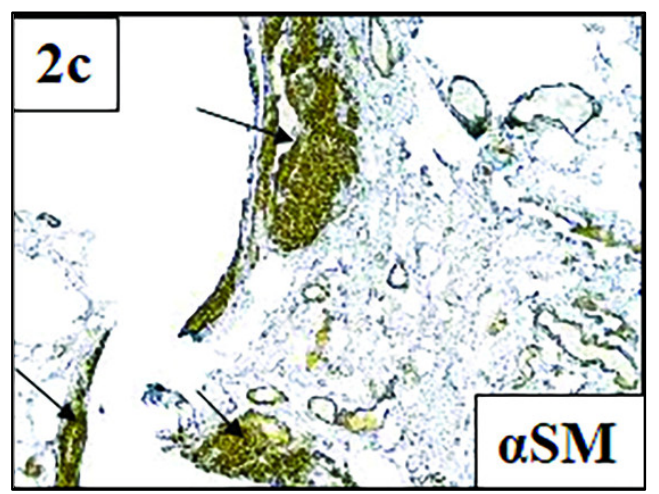

Figure 2c. $\alpha \mathrm{SM}$ actin expression in the proliferative spindle cells that confirms their smooth-muscle origin (arrows) x 10

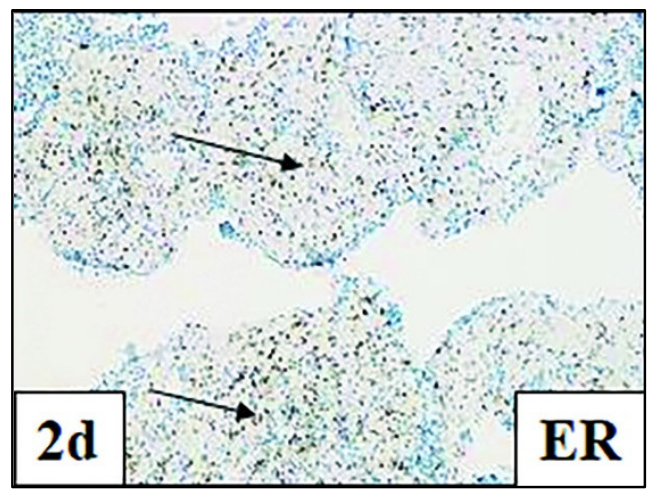

Figure 2d. Expression of steroid estrogen receptor confirms hormonal dependence of LAM and its most common clinical manifestation during hormonal imbalance (arrows) $\times 10$ 


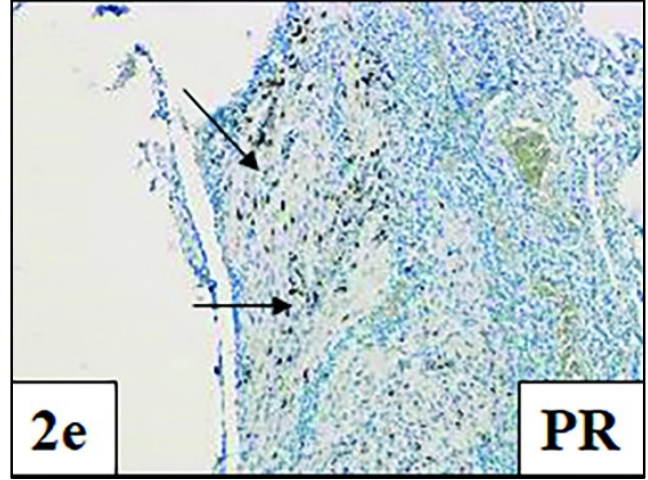

Figure 2e. Expression of steroid progesterone receptor in a few tumor cells (arrows) $x 10$

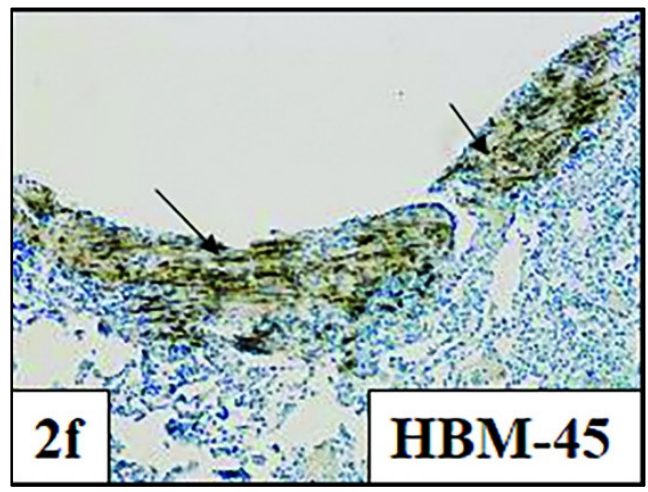

Figure 2f. HBM-45 expression in spindle cell confirms diagnosis of LAM, (arrows) $\times 20$

A few days after the first, a second intervention of the same type was done in the right lung which had the same changes present but of some lower intensity.

After bilateral surgery, recovery and concurrent pathohistological diagnosis of LAM, our patient should start with the treatment.

\section{DISCUSSION}

According to the 2015 WHO Classification of Lung Tumors, LAM belongs to the group of PEComatous tumors, together with benign and malignant PEComatous tumors and "clear cell" tumor. All tumors in this group are characterized by focal or diffuse expression of HBM-45 [1].

The morphological picture of LAM is characterized by the presence of cystic spaces covered by single-row, flat endothelial cells expressing podoplanin (clone D2-40) under which are focally located multiplied proliferations of spindle cells expressing $\alpha \mathrm{SM}$-actin. Between these cells are present those expressing steroid receptors, estrogen and progesterone and those with diffuse and cytoplasmic expression of HBM45. According to some authors, if there is no HBM-45 expression it is about lymphangiomyomatosis. In the first sample in our patient changes are more pronounced than in the other which has also been described in the available literature. Although changes were of varying intensity, both caused pneumothorax $[1,3,4,5]$.

The literature has described cases of LAM that caused pneumothorax in the last trimester of pregnancy and shortly after birth. This phenomenon is explained by the fact that hormonal stimulation during pregnancy leads to an increase in cystic structures and at the end of pregnancy or shortly after delivery it comes to decline in hormonal stimulation and consequently to the rupture of some of the thin wall cystic structures and onset of pneumothorax. This also explains the fact that LAM is almost typically a female disease $[3,5]$.

LAM can be associated with other diseases but it can be also an independent disease. The Polish authors analyzed 15 pathohistologically diagnosed LAMs and in 6 of them there was no present an associated disease as well as in our patient [5].

After the diagnosis of LAM, the pulmonologist should start treatment with target therapy. Treatment for LAM is based on its etiology. LAM occurs as congenital (TSC-LAM) or acquired (sporadic or S-LAM) tumor supressor tuberous sclerosis complex (TSC) gene mutation in TSC1 (hamartin) or TSC2 (tuberin). The TSC1-TSC2 complex is incorporated into various signal pathways and it is also involved in the regulation of the target of rapamycin complex. In most LAM tumor tissue, there are either TSC1 or TSC2 mutations, but in $10-15 \%$ it is not determined presence of TSC gene mutations. Numerous studies have included the effects of sirolimus which is mechanical target of rapamycin (mTOR) inhibitors. Other molecular - target drugs are also being investigated. If LAM does not respond to these drugs only treatment option is bilateral lung transplantation $[6,7,8]$.

\section{CONCLUSION}

Lymphangioleiomyomatosis is a rare lung tumor manifested by a dramatic clinical picture. In our patient, end of pregnancy caused a decrease in hormones, estrogens and progesterone, which was manifested by lymphangioleiomyomatosis in the form of bilateral spontaneous pneumothorax.

\section{REFERENCES}

1. Travis WD, Brambilla E, Nicholson AG, Yatabe Y, Austin JHM, Beasley MB, Chirieac LR, Dacic S, Duhig E, Flieder DB, Geisinger K, Hirsch FR, Ishikawa Y, Kerr KM, Noguchi M, Pelosi G, Powell CA, Tsao MS, Wistuba I; WHO Panel. The 2015 World Health Organization Classification of Lung Tumors: Impact of Genetic, Clinical and Radiological Advances Since the 2004 Classification. J Thorac Oncol. 2015; 10(9): 1243-60. 
2. Silva DL, Pinto P, Costa M, Maia R, Rodrigues C. Pneumothorax as a Presentation of Tuberous Sclerosis Associated Lymphangioleiomyomatosis. Eur J Case Rep Intern Med. 2019; 6(10): 001264.

3. Crawford TC, Grimm JC, Magruder JT, Stephens RS, Sciortino CM, Vaught AJ, Althaus J, Shah AS, Kim BS. A curious case of acute respiratory distress syndrome. J Surg Case Rep.; 2015(11) pii: rjv140.

4. Pais F, Fayed M, Evans T. Lymphangioleiomyomatosis: an explosive presentation of a rare disease. Oxf Med Case Reports. 2017; 2017(6):omx023.

5. Grzegorek I, Lenze D, Chabowski M, Janczak D, Szolkowska M, Langfort R, Szuba A, Dziegiel P. Immunohistochemical evaluation of pulmonary lymphangioleiomyomatosis. Anticancer Res. 2015; 35(6): 3353-60.
6. $\mathrm{Xu} \mathrm{KF}$, Lo BH. Lymphangioleiomyomatosis: differential diagnosis and optimal management. Ther Clin Risk Manag. 2014; 10: 691-700.

7. Hu S, Wu X, Xu W, Tian X, Yang Y, Wang ST, Liu S, $\mathrm{Xu} \mathrm{X}, \mathrm{Xu} \mathrm{KF}$. Long-term efficacy and safety of sirolimus therapy in patients with lymphangioleiomyomatosis. Orphanet J Rare Dis. 2019;14 (1):206

8. Johnson SR, Cordier JF, Lazor R, Cottin V, Costabel U, Harari S, Reynaud-Gaubert M, Boehler A, Brauner M, Popper H, Bonetti F, Kingswood C; Review Panel of the ERS LAM Task Force. European Respiratory Society guidelines for the diagnosis and management of lymphangioleiomyomatosis. Eur Respir J. 2010; 35(1):14-26. 